\title{
Geweld en geweldloosheid in Openbaring
}

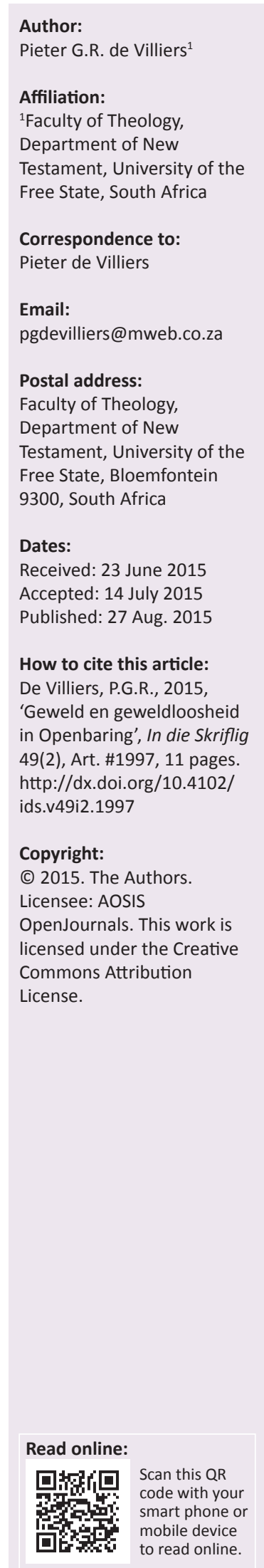

Hierdie artikel ondersoek die algemeen aanvaarde interpretasie van Openbaring as 'n boek met 'n nie-gewelddadige boodskap wat sy lesers oproep om nie wraak te neem teen hulle vyande en vervolgers nie. In die eerste afdeling van die artikel word sommige van die belangrikste redes vir hierdie interpretasie ondersoek. Daarna word bespreek hoe die diepsinnige niegewelddadige boodskap met gewelddadige taal en inhoude gekombineer en aangebied word. Eerstens word dus aandag gegee aan die oproep tot die lesers om nie geweld te beoefen nie, aan die lewering van getuienis, aan die vergeesteliking van die oorlogstaal en aan goddelike geweld. Daarna ondersoek die artikel in meer diepte hoe die geweldlose boodskap van die boek ingebed is en gekarakteriseer word deur geweldstaal, hoe die skynbaar positiewe uitbeelding van vroue met gender-geweld deurspek is en hoe uitermatig gewelddadig die goddelike oordeel is. Die artikel eindig met kort hermeneutiese opmerkings oor hoe die gewelddadige aspekte van Openbaring se geweldlose boodskap benader kan word.

Violence and non-violence in Revelation. This article questions the widely accepted interpretation of the Revelation of John in the New Testament as a book with a non-violent message that calls on its readers to refrain from vengeance. First of all, after a discussion of some good reasons for this interpretation, the article subsequently points out how the profound non-violence of the message is combined with and presented in violent language. Attention is therefore paid to Revelation's message to its readers to refrain from violence, to its call to witness, its spiritualising of war-like language and its focus on divine judgement. The article then investigates in more depth how the non-violent message of the book is embedded in and characterised by violent language, how its seemingly positive portrayal of women is in fact permeated by gender violence and how it portrays a divine violence that has an extremely violent nature. The article concludes with brief hermeneutical remarks that reflect on how the violent dimensions of Revelation's non-violence can be interpreted.

Openbaring word as 'n kroongetuie in die Nuwe Testament vir die nie-gewelddadige karakter van die vroeë Christendom beskou. Die hoofkarakter in die boek is immers die geslagte Lam wat die geweld van sy opponente teenoor Hom sonder fisieke reaksie en weerwraak verduur het, terwyl die gelowige gemeente in die boek uitgebeeld word as mense wat deur getuienis eerder as geweld hulle teenstanders opponeer. Die boek stuur voorts af op 'n toekomstige vredestoestand met die terugkeer van die paradys wat die lang gewelddadige wêreldgeskiedenis sal beëindig en mense van geweldenaars tot vredesvolkere sal omvorm (Op 21-22). ${ }^{1}$ Trane, die dood, leed, smart en pyn, en die tekens van 'n vervloë, bose tyd van geweld sal nie meer ervaar word nie (21:4). Die klimaktiese sewende trompet word immers in 11:15-18 aangekondig met die slotopmerking (opvallend genoeg geformuleer in terme van geweld) dat goddelike oordeel oor die 'woedende nasies' sal aanbreek: hulle - dit is dié 'wat die aarde vernietig - word vernietig'. In 'n idilliese toneel, word die ondenkbare uiteindelik 'n konkrete werklikheid: die nasies stroom die nuwe Jerusalem binne en leef in die stad se lig (21:24-26). In die boek beteken geweldloosheid dus dat God mense van hulle vyandige, vernietigende lewensstyl en optrede wil bevry, vir hulle die vrede as hulle skeppingsbestemming wil herstel en hulle tot egte menswees as skepsels wat in 'n intieme verhouding met God leef wil transformeer.

Hierdie verhaallyn en boodskap veronderstel 'n bepaalse etos met belangrike etiese implikasies. Johns (2003:187) is byvoorbeeld een van vele navorsers wat die funksie van die boek in terme van nie-gewelddadigheid beskryf en dit dan veral aanprys vir die uitstaande etiek daarvan. Dit is vir hom 'n boek wat konsekwent aanmoedig tot' $n$ algemene vredes-etos van nie-gewelddadige verset teen die bose en dus sy lesers tot ' $n$ etiek van nie-gewelddadige getuienislewering oproep. Daar is dus ' $n$ navorsingstradisie wat sterk fokus op Openbaring as ' $n$ boek wat nie-gewelddadigheid bevorder. 
In 'n kontemporêre konteks waarin geweld toenemend as 'n akute probleem binne die samelewing onder die loep geneem word, kan dit verwag word dat hierdie siening sterk gepropageer sal word. Elke moontlike ondersteuning, veral uit die grondtekste van die Christendom om geweld te bestry, is immers nuttig en nodig. Die appropriasie van die Nuwe Testament binne die horison van interpretasie bevorder dus die nie-gewelddadige siening van Openbaring se boodskap.

Hierdie nie-gewelddadig interpretasie van Openbaring word dikwels verbind met 'n soortgelyke siening van die res van die Nuwe Testament waarvolgens die hele Nuwe Testament as 'n vredesboek uitgebeeld word. Daarmee word hierdie algemene vertrekpunt in 'n kringloopargument, 'n verdere bril waarmee individuele boeke soos Openbaring ook as nie-gewelddadig gelees word. Daar word geskryf dat Openbaring nie-geweldddadige tradisies in die res van die Nuwe Testament bevestig en dat dit in ooreenstemming is met die vroeë Christendom as 'n vredesbeweging. Hays (1997) kan daarom in sy invloedryke publikasie oor etiek die volgende skryf: 'from Matthew to Revelation we find a consistent witness against violence and a calling to community to follow the example of Jesus in accepting suffering rather than inflicting $i^{\prime}{ }^{2}$

Onlangse navorsing begin hierdie gevestigde aanname van vele navorsers oor die Christendom as ' $n$ vredesbeweging egter toenemend bevraagteken. In 'n wydgelese werk van Crossan (2007) het hy byvoorbeeld die aandag op twee Godsbeelde in die Nuwe Testament gevestig wat in konflik met mekaar is, terwyl hy in 'n latere werk (Crossan 2015) geweld en vrede as twee kompeterende gesigte van die Christendom uitwys. ${ }^{3}$ Openbaring, met sy voorstelling van die straffende oordeelsgeweld van God, verteenwoordig, volgens hom, 'n tweede trajek wat van die beskrywing van God as 'n nie-gewelddadige God van vrede verskil. Onlangs het hy in 'n besondere sterk uitspraak selfs Openbaring as waarskynlik die mees gewelddadige boek in die kanonieke tekste van alle godsdienste beskryf.

Sy opmerkings is maar een voorbeeld van al hoe meer publikasies, ook in 'n Suid-Afrikaanse konteks, wat daarop wys dat geweld endemies in sommige Christelike tekste en denke is, en wat die verborge en openlike vorme van geweld in die Nuwe Testament as 'n besondere probleem uitwys. Vanuit 'n hermeneutiese hoek word daarop gewys hoe dubbelsinnige taalgebruik en gapings in sulke tekste juis die weg baan vir kerke en randgroepe wat geweld bevorder. ${ }^{4}$ Die resepsiegeskiedenis wys immers hoe randgroepe en selfs gevestigde kerke, wat andersins vrede verkondig het, Openbaring by tye gebruik het om geweld te bevorder en

2. Hays (1997:332) skryf byvoorbeeld: 'there is not a syllable in the Pauline letters that can be cited in support of Christians employing violence. Paul's occasional uses of
military imagery ... actually have the opposite effect: the warfare imagery is drafted military imagery ... actually have the opposite effect: the warfare imagery is
into the service of the gospel, rather than the reverse' (kyk ook pp. 335-337).

3.Kyk die abstract by http://www.johndominiccrossan.com/How\%20to\%20Read\%20 the\%20Bible.htm.

4.Kyk byvoorbeeld De Villiers (2013:245-283). Vir'n algemener bespreking, kyk Huber (2010). te verdedig. ${ }^{5}$ Dit word beklemtoon dat Openbaring nie die 'slagoffer' van moedswillige of oningeligte misbruik van bybelse tekste is nie, maar wel ruimte skep vir sulke lesings.

In hierdie nuwe ondersoekende besinning oor Openbaring was daar tot dusver 'n opvallende tendens. Analitiese navorsing het steeds weer op óf nie-gewelddadige óf gewelddadige uitsprake van Openbaring gefokus. Min uitdruklike besprekings is beskikbaar oor die verhouding tussen hierdie twee aspekte, met net so min aandag aan die wyse waarop hulle mekaar beïnvloed. In hierdie artikel word daarom die twee aspekte se verhouding ondersoek om die behoefte aan ' $n$ presiese en nadere besinning daaroor aan te spreek. Nadat ontleed is watter faktore gebruik word om Openbaring se diepsinnige vredesboodskap uit te beeld en te motiveer, word drie argumente aangevoer waarom die prominente tema van nie-gewelddadigheid aangetas word: dit het te doen met die aard van die boek se taal, die sosiale diskoers onderliggend aan die vroulike simboliek en met die boek se beeld van God as regter. Daarmee word aangedui dat en hoe die twee in noue verband met mekaar staan, en meer nog, dat die nie-gewelddadigheid van Openbaring self gewelddadig is. Ironies genoeg en skerp gestel, skuil geweld in geweldloosheid. In 'n slotgedeelte word kortliks aandag gegee aan die hermeneutiese en etiese implikasies vir die uitleg van die boek en vir Nuwe Testament as dissipline. Die beperkte ruimte laat slegs enkele opmerkings hieroor toe.

\section{'n Nie-gewelddadige boek}

Onder die uitsprake, simbole en motiewe wat onteenseglik daarop dui dat Openbaring wegskram van geweld, kan veral drie uitgesonder word. ${ }^{6}$

\section{Geweldloos}

Een van die opvallendste kenmerke van Openbaring is sy etos wat nêrens van gelowiges enige weerwraak of gewelddadige optrede teenoor hulle geweldenaars vra nie. Soos in ander Nuwe-Testamentiese boeke, roep Openbaring nie op tot oorlog, militêre aksies, revolusie of tot fisieke wraakoptrede teen vyande of verdrukkers nie. Hierin verskil die boek van Ou-Testamentiese tekste waarin Israel se oorlogsvoering teen hulle vyande breedvoerig beskryf word en stem dit ooreen met ander Nuwe-Testamentiese tekste. As gevolg hiervan staan die lesers van Openbaring uit tussen ander groepe uit die Grieks-Romeinse tydperk wat by tye gewelddadig in opstand teen hulle maghebbers gekom het. ${ }^{7}$ 5.Die berugte kruistogte bied'n goeie voorbeeld van hierdie gebruik van die Bybel. Die
invloedryke kerkleier en teoloog, Bernard van Clairvaux, het sy gehoor byvoorbeeld
met die simbool van die nuwe Jerusalem in Openbaring opgeroep tot die krygstog
na Jerusalem. Die Hussietiese Taboriete van Bohemië (15 n.C.) het beweer dat
ongelowiges as vyande van Christus vermoor moes word omdat Openbaring se
verwagting van die Ryk van die Antichris aangebreek het. Kyk Kaminsky (2004:342)
oor die gesofistikeerde groepe agter die Taborietiese revolusies. Vir onlangse
voorbeelde van geweldsresepsie van die Bybel en Openbaring, kyk Jurgensmeyer
(2003), Rossing (2005) en Kippenberg (2011).

6.Kyk Streett (2012) en Lawrence (1960) vir vele voorbeelde (kyk ook Bredin 2012; Johns 2003:202-203; Mueller 2011:62-63 en met meer versigtigheid, oordeel Collins 1983).

7.Kyk byvoorbeeld Brighton (2009:2-11; kyk ook Martin 2011) vir 'n omvattende oorsig oor navorsing oor die Sicarii as voorbeeld van sulke revolusionêre groepe wie se optrede sterk in kontras staan met ander groepe wat toenemend gewelddadige optrede gekritiseer het, veral na die Joodse oorlog (66-100 n.C.). 
Hierdie etos val veral op omdat geweld 'n prominente tema in die boek is. Geweld is volgens die skrywer immers die primêre reaksie van die bose op God se werk in Christus. Trouens, die bose triade van die draak en die twee diere teer op geweld teenoor die geloofsgemeenskap en die wêreldnasies. Die skrywer verwys ook herhaaldelik na die gewelddadige dood en optrede teen Christus, veral met sy kruisiging. Sy opponente word beskryf as dié wat hom deurboor het

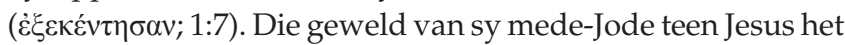
verreikende gevolge: Onvoorstelbaar binne 'n Joodse konteks is dat Jerusalem, die heilige stad, weens die gewelddadige kruisiging nou beskryf word as die 'groot stad' wat lyk soos Sodom en Egipte, bekend as die berugste voorbeelde van antigoddelike magte in die heilsgeskiedenis (11:8). Die geweld is des te meer opvallend en aanstootlik omdat Christus die onskuldige, die geweld teen Hom verduur eerder as wreek, en sy lewe boonop as liefdevolle heilsdaad gee om mense van die bose te bevry $(1: 5 ;$ kyk ook 5:12; 6:1;12:11; 13:8; 14:1, $4 ; 17: 14 ; 19: 7)$. Christus se dood en die vergieting van sy bloed bring geweld tot 'n einde (12:11; 1:5; 5:6, 9; kyk ook 7:14).

Hierdie voorstelling van die geweldlose Lam is fundamenteel vir ander gedeeltes in Openbaring wat 'n nie-gewelddadige etos voorhou aan die lesers. Christus se selfopofferende dood word die motivering vir en model van die lewe in geloof. Gelowiges van die Lam 'volg' hom ook hierin. Hulle weerstaan die geweld van die bose sonder om self gewelddadig te word, selfs al lei dit tot hulle dood. Hulle is oorwinnaars deur die bloed van die Lam en nie deur fisieke oorlog teen die bose nie (12:11). Geweld word deur hulle verduur, nie uitgedeel nie (kyk bv. 2:10, 13; 6:12).

\section{Getuienis}

Die nie-gewelddadige Christologie en etos van Openbaring word verder ook bevestig deur die skrywer se herhaalde beskrywing van sy eie en gelowiges se 'getuienislewering'. Getuienislewering is 'n sleutelmotief in Openbaring en dra beslissend by tot die karakterisering van gelowiges se identiteit: Jesus is die getroue getuie $(1: 5 ; 3: 14$; kyk ook 22:20). Johannes beskryf homself as getuie (1:2) en die geloofsgemeenskap vind hulle identiteit in getuienislewering aan die nasies. Die getuienis is besonder uitdagend en moeilik (2:3), want dit het 'n nie-gewelddadige karakter soos blyk uit die duur prys wat hulle betaal - soms selfs met hulle lewens. ${ }^{8}$ Johannes word volgens die inleiding na Patmos verban omdat hy die getuienis van Jesus verkondig (1:9). Die gemeentelid, Antipas, 'n 'getroue getuie', word doodgemaak (2:13), sommige word in die tronk gegooi (2:10) en ander sterf omdat hulle vasgehou het aan die 'getuienis van Jesus' (6:9). Die prostituut, as die laaste, gevaarlike vyand van die gelowiges, verskyn in 'n visioen aan Johannes 'dronk ... van die bloed van die gelowiges, van die bloed van die mense wat vir Jesus getuig het' (17:6).

Veral opvallend is die getuienis en die plasing daarvan in die groter verhaallyn van Openbaring. Dit blyk eerstens uit die

8.Kyk ookbyvoorbeeld Rossing (2005) en veral die uitgebreide bespreking van Bauckham (1993:210-237). episode van twee 'getuies' wat die bose om die lewe bring nadat hulle in die groot stad hulle getuienis gelewer het (11:7) wat die sentrale posisie van getuienis in die boek aandui. Hulle is nietemin kragtige getuies met 'n vurige getuienis (11:5) wat die lewe van die kerk simboliseer. Na hulle aan die einde van die toneel verwyder is, volg die volle aanslag van die bose triade (die draak en twee wilde diere) teen die geloofsgemeenskap in die tweede deel van Openbaring (hfst. 10-19). Met hierdie episode word getuienislewering in die hart van die boek beklemtoon en uitgespel as die enigste reaksie op die gewelddadige vervolging wat gelowiges ly. ${ }^{9}$

Die skrywer van Openbaring beklemtoon die belangrikheid van getuienislewering deur dit ten nouste met sy geweldlose Christologie te verbind. Volgens 12:11 het gelowiges die oorwinnig behaal deur die bloed van die Lam en hulle getuienis. Dit is die raamwerk waarteen die bediening van die twee getuies verstaan moet word. Hulle volg met hulle profetiese optrede die voorbeeld van die Lam in die vyandige groot stad. Hulle word daarom doodgemaak in die stad waar Christus gekruisig is (11:8). Soos Christus, betaal hulle ook die hoogste prys: Hulle word deur die dier doodgemaak (11:7). Soos met Christus loop hulle getuienis, soos met hulle opstanding en hemelvaart (11:11-12), uiteindelik op 'n triomf uit. Groot vrees oorval hulle teenstanders sodat hulle aan God die eer gee (11:13). In hulle getuienis is die krag van God aan die werk. ${ }^{10}$ Die parallelle tekening van Christus en die getuies is presies dieselfde: albei getuig sonder geweld en albei ervaar goddelike bevestiging vir hulle opofferende getuienis.

Die nie-gewelddadigheid van die getuienis word verder ook deur die profetiese aard daarvan uitgespel. Die twee getuies word nie verniet twee 'profete' in 11:10 genoem nie. Deur hulle profetiese optrede soek die getuies die bekering van die nasies en nie hulle vernietiging nie (bv. 9:20-21; 14:6-7, vgl. 11:13). ${ }^{11}$ Die positiewe verhouding tot die nasies blyk verder uit 21:24-26 waar die nasies deel van die nuwe bedeling kry. Hulle word nou ook deel van God se volk:

Therefore, the reason that Rev. 21:24-26 refers to the nations bringing glory and honor into the city is to highlight that they are bringing not literal riches but themselves as worshipers before God's end-time presence (so 22:3-5). (Beale 1999:1095)

In die boek as geheel word die herstel van die nasies dus gepropageer: uiteindelik moet geweld tot 'n einde kom en die nuwe paradys gevestig raak waarin almal, ook die geweldenaars teen gelowiges, sal deel. Dit alles lei nie net tot die uitskakeling van geweld nie, maar word deur niegewelddadigheid bereik.

\footnotetext{
9.Satake (1966) is een van die weinige navorsers wat argumenteer dat Johannes nie belangstel in die kerk se getuienislewerende taak nie.

10.Kyk Mueller (2011:42-66) vir'n deeglike beskrywing van die weerlose en kragtige dimensies van die Christologie in Openbaring.

11.Dit is in lyn met die soteriologiese karakter van die boek (1:5). Bauckham (1993:238-337) bespreek bekering as die sentrum van Openbaring se boodskap, (1993:238-337) bespreek bekering as die sentrum van Openbaring se boodskap,
veral in die lig van die boek se profetiese karakter. Die skrywer fokus sterk op sy profetiese boodskap wat die nasies tot bekering oproep. Hy wys daarop dat hierdie profetiese boodskap wat die nasies tot bekering oproep. Hy wys daarop dat hierdie tot die Ou Testament nie genoeg in ag geneem word nie.
} 


\section{Vergeesteliking}

Nog 'n opvallende aanwysing van Openbaring se niegewelddadige taal is die wyse waarop die skrywer gewelddadige taal uit sy tradisies oorneem en dit van sy letterlike toepassing ontneem deur daaraan 'n geestelike betekenis toe te ken. Hierdie vergeesteliking versterk die vorige opmerkings dat gelowiges nie tot fisieke opstand of weerwraak aangespoor word nie. ${ }^{12}$ Openbaring is bekend vir sy uitgebreide gebruik van die heilige oorlogsmotief wat in die Ou Testament wys op Jahwe as die goddelike Kryger wat as koninklike Heerser Israel tot oorwinning aanvoer..$^{13}$ In 19:11-21, byvoorbeeld, pas die skrywer hierdie militaristiese tradisie op Christus toe: Hy is te perd, het 'n swaard, is in koninklike drag, regeer met 'n septer en trek op met 'n leër om oorlog te maak (Jes 62:2-3; 11:4b, 49:2; 63:3; Joël 3:13). ${ }^{14}$

Daar is, nietemin, duidelike verskille tussen bogenoemde en die militaristiese beeld van die tradisionele kryger. Die skrywer vergeestelik die heersersfiguur deur Hom 'baie' heerserskrone en 'n bloeddeurweekte kleed te laat dra, die swaard uit sy mond te laat kom en Hom die Woord van God te noem ${ }^{15}$ (kyk ook 1:16; 2:16; 19:15, 21).

Hierdie vergeesteliking kom in die res van die boek ook voor. Reeds in die eerste visioen (1:12-20) word die Menseseun uitgebeeld as die beskermer van die gemeentes met die beeld van sewe sterre wat Hy in sy regterhand vashou, terwyl daar 'n swaard uit sy mond kom as teken van sy oordeel (1:16). Later waarsku die skrywer die gemeente in Pergamum dat die Menseseun vir die Nikolaïete met die swaard van sy mond sal aandurf (2:16). Die motief van die swaard word hier vergeestelik om eerder die goddelike oordeel uit te druk. 'The sword in these vignettes symbolizes the irresistible power of divine judgment', skryf Mounce (1988:60). In Openbaring 11 pas die skrywer dieselfde simbool ook op die kerk toe wanneer hy skryf dat die twee getuies profeteer met die swaard van hulle mond. Die simbool van die swaard is dus nie letterlik'n fisieke swaard as aanvalswapen in die hand van die Menseseun nie, maar ' $n$ simbool van die oordeel oor die gewelddadige opponente. ${ }^{16}$ Die nie-gewelddadige aard van die simbool word verder bevestig deur die groter stryd waarin dit funksioneer: die Lam as aanvoerder van die stryd teen die bose tree nie-gewelddadig op teen die bose wat op dodelike geweld ingestel is (bv. 6:4 - deur 'n swaard; 13:6, vgl. v. 15). Die laaste, klimaktiese aanklag in die visioen van

12.0p'n konkrete vlak sou dit kon beteken dat die groep waarin Openbaring gelees is, konflik met die owerhede en gesagsinstansies wou vermy omdat hulle ' $n$ minderheidsgroep was wat nie so 'n konfrontasie kon bekostig nie. In die lig van ander minderheidsgroepe wat wel opstand teen die staat aangeblaas het, is so 'n interpretasie in die geval van Openbaring onwaarskynlik. Latere lesers het die boek in elk geval as ' $n$ sterk kritiek op die Romeinse owerhede gelees - soo byvoorbeeld blyk uit die kommentaar van Oecumenius. Dit is onwaarskynlik dat lesers van Openbaring die konfrontasie met die owerhede daarom sou mislees.

13. Kyk Bauckham (1993:85) vir'n uitvoerige bespreking. Let byvoorbeeld op hoe 7:2-14 die tradisionele oproep tot oorlog vergeestelik (kyk ook Finamore 2001:213).

14.Kyk Longman (1982) vir meer inligting. Hy gee ook 'n oorsig oor navorsing van die tema van die begin van die twintigste eeu met die publikasie van Schwally sowel as die invloedryke werk van Von Rad.

15.Kyk Aune (1998:475) en Beale (1999:438) vir die metaforiese aard van die uitdrukking.

16.Die swaard is skerp en tweesnydend om die intensiteit van die oordeel uit te beeld. die prostituut (Op 17-18) is immers dat Babilon skuldig is aan die bloed van die profete en die gelowiges, 'almal wat op die aarde doodgemaak is'. ${ }^{17}$ Uiteraard is die Lam en sy volgelinge deel van 'n nie-gewelddadige sfeer en konteks wat teenoor sulke geweld staan.

\section{Goddelike oordeel}

Ten nouste verbonde met die voorafgaande niegewelddadige dimensies, is Openbaring se uitbeelding van die goddelike oordeel. Die boek onderstreep dat gelowiges God moet vertrou om hulle vervolgers te straf eerder as wat hulle sake in eie hande neem. Dit blyk uit die reeks visioene in die hoofdeel van Openbaring (hfst. 7-19) wat op 'n hoë noot begin met die episode oor die gelowiges wat as gevolg van hulle getuienis geslag ${ }^{18}$ is (6:9). Hulle vraag wanneer God hulle moordenaars gaan oordeel, bied 'n perspektief op Openbaring se verstaan van die goddelike oordeel. Die 'geslagtes' vra: 'Hoe lank nog, heilige en getroue Heerser? Wanneer voltrek $U$ die oordeel en wreek $U$ ons dood op die bewoners van die aarde?'(6:9-10; vgl. 7:14; 14:1-5). ${ }^{19}$ Die antwoord laat blyk dat gelowiges God moet vertrou om hulle vervolgers te straf. In hulle vraag sowel as in die antwoord daarop is daar geen aanduiding dat hulle sake in eie hand neem om oordeel te voltrek of wraak te neem nie. Inteendeel, hulle kry as antwoord dat hulle moet wag tot die dood van hulle medegelowiges omdat God op sy tyd teen hulle opponente sal optree. ${ }^{20}$ Onderliggend aan hierdie antwoord is dat God ongetwyfeld die bose sal oordeel, ${ }^{21}$ maar intussen is enige ander vorm van geweld deur die volgelinge van God wat sy werk wil oorneem, buite die kwessie.

\section{Gewelddadige geweldloosheid}

Dit lyk asof bogenoemde vier argumente die niegewelddadigheid van Openbaring oortuigend bewys. Tog is daar in die boek self uitsprake en beskrywinge wat vrae oproep oor hoe konsekwent nie-gewelddadigheid in die

17.Kyk Bauckham (1993:349) vir die vervlegtheid van ekonomiese en godsdienstige taal om die militêre en politieke brutaliteit van die bose uit te druk.

18.Die woord wat hier gebruik word, is besonder sterk (hulle wat 'geslag' is). Die impak daarvan word bevestig deur die gebed van die geslagtes wat vra wanneer hulle 'bloed' gewreek gaan word. Beale (1999:390) lees die werkwoord as metafories vir gelowiges wat vir hulle geloof vervolg is. Müller (1995:170-171) verbind die woord geslag en bloed met die offerande by die brandofferaltaar. Hoewel die opmerkings ter sake mag mees, wil die skrywer met hierdie woord die gewelddadige dood van die geslagtes uitbeeld in die lig van die lot van Christus (kyk 5:6, 9, 12; 13:8). Hy beklemtoon daarmee dat hulle met Christus 'n gewelddadige einde deel.

19.Klassen (1966:300-311) is ' $n$ voorbeeld van 'n verleentheidshipotese wanneer hy argumenteer dat hierdie uitspraak nie te doen het met wraakneming nie, maar God se offerhandeling in Christus vindikeer. Soos hier onder sal blyk, is die 'vindikering' van Jesus in die res van Openbaring soms uiters gewelddadig.

20. Hierdie verstaan van die goddelike oordeel veronderstel ' $n$ skeppingsteologie wat aanvaar dat die wêreld en mens sonder geweld geskape is, maar na die rebellie van engele teen God verval het in ongeregtigheid, boosheid en geweld (12:7-9; Bauckham 1993:47). Daar sal ' $n$ terugkeer na die oorsprongsituasie wees met die koms van die nuwe hemel en aarde (21:24). God stuur hierdie proses, soos blyk uit 11:17-18 (kyk ook Finamore 2001:213-214). Hierdie opmerkings is van groot belang om die waarde en karakter van vrede te verstaan.

21.Dit beteken nie dat gelowiges passief is terwyl hulle op God vir die finale oordee vertrou nie. Hulle is veral in hulle getuienislewering deel van ' $n$ kosmiese konflik tussen die goed en kwaad. Die skrywer van Openbaring gebruik juis daarom oorlogstaal om sy lesers aan te spoor tot aktiewe verset teen die kwaad. Bauckham (1993:40,69-70) noem dit 'n versigtige herformulering van militaristiese taal vir nie-militêre doeleindes. Dit is inderdaad so, maar so'n aansporing kan onbedoelde gevolge hê, veral wanneer lesers die doeleindes mislees. 
boek voorkom. Die boek is, selfs in sy uitbeelding van niegewelddadigheid, in sekere opsigte 'n gewelddadige stuk werk waarin die menslikheid van ander aangetas en vernietig word. In navorsing word hierdie gewelddadige aspekte dikwels geïgnoreer, onderspeel, goedgepraat of vergeestelik. Dit gebeur wanneer aan die uitsprake ' $n$ bepaalde positiewe funksie toegeskryf word.22 Dit gebeur ook wanneer die gewelddadigheid gelate aanvaar word as 'n teken van 'n vergange tyd waarin ander norme oor geweld gegeld het of as 'n ongelukkige oorblyfsel in die denke van 'n onbekwame skrywer wat die volle impak van die evangelie nie kon peil en verwoord nie.

Al hierdie onsuksesvolle en onbevredigende pogings bevestig eerstens die probleem dat die geweldloosheid van Openbaring dreig om verduister te word deur sy donker, gewelddadige kant. Wat die situasie ingewikkelder maak, is dat geweldloosheid en gewelddadigheid nie maar net losweg naas mekaar voorkom nie, maar onlosmaaklik vervleg is. ${ }^{23}$

\section{Gevaarlike taal en sy ideologiese onderbou}

Openbaring se geweldlose boodskap met sy edele ideale van getroue getuienislewering en martelaarskap is, paradoksaal, in gewelddadige oorlogstaal uitgebeeld. Lesers word wel vertel om nie gewelddadig te wees of weerwraak te neem nie, maar dit word gedoen deur en in 'n wrede, donker en vernietigende verhaal oor bloedvergieting en oorlog (12:7-8; $16: 14 ; 17: 14 ; 19: 11,19)$, met bloedstollende moordtonele (9:1-6; $11: 7 ; 13: 7)$, en angsaanjaende rampe en plae (9:20). Selfs die eerste septet, naamlik die briewe aan die sewe gemeentes wat Christus beskermend in sy hand sou hou (Op 2-3), lewer 'n aansienlike kwota van dreigemente en vervloekinge op in 'n konteks waarbinne 'n mens dit nie sou verwag nie. Die daaropvolgende septette van seëls, trompette, skale en engele (Op 6-16) lewer die lesers uit aan uitgebreide skrikbeelde van goddelike oordeel oor die magtiges van die aarde en hulle gemeenskappe (6:1-15). ${ }^{24}$ Die stryd teen die Bose in Openbaring eindig met die Ruiter op die wit perd (nou nie meer 'n geweldlose Lam nie) wat die hemelse leërskare in die laaste oorlog teen die nasies aanvoer om hulle te vernietig as teken van die toorn en oordeel van God (19:11-16). Die slagting eindig met ' $n$ makabere toneel van voëls wat aas op en hulle dik eet aan die vlees van die skrywer se opponente (19:17-21).

22.Dit gebeur gewoonlik wanneer hulle plek in 'n kanonieke teks verdedig word deur navorsers met' $n$ bepaalde ortodokse houding oor die kanon. Die doodmaak van die vrou Isebel se kinders in 2:23 word byvoorbeeld deur Roloff (1984:57) beskryf as ' $n$ 'rigoreuse' poging om die reinheid van die gemeente te soek eerder as ' $n$ vergeldingsuitspraak. Die siening kyk te maklik verby die implikasie dat die doodmaak van kinders aan God toegeskryf word.

23.Die kommer hieroor is nie nuut nie. Verskeie onlangse wetenskaplike ontwikkelinge het hierdie ondersoek meer pertinent en sistematies na vore gebring. Dit sluit in nuwere linguïstiese insigte in die vernietigende impak van taal, dekonstruksie, postkolonialisme en die hermeneutiek van suspisie se analises van (gewelddadige) mastkond in en deur tekste. Dit sluit ook in die bisewuswording in (gewelddadige) magstryd in en deur tekste. Dit sluit ook in die bewuswording in geweldstudies van uitgesproke en verborge vorme van geweld wat ook in Bybelse tekste na vore kom (De Villiers 2013). Antieke skrywers het egter al geworstel met die kwessie soos
blyk uit oorskrywers se emenderings van geweldsuitsprake in Bybelmanuskripte (kyk hiervoor Hernandez 2006:90-95, 129-131).

24.Neufeld (2011:124-129) sowel as Farmer (1997:115ff.) bied waardevolle besprekings van die gewelddadige inhoud van die boek.
Die beskrywinge van God se vyande is nie minder grusaam nie. Die skrywer kraak hulle af deur die retoriek van vilifikasie as gewelddadige, gevaarlike wilde diere wat mense treiter en vermoor (9:7-11, 17-20). ${ }^{25}$ Die mag van die hemelse en goddelike figure word weliswaar aangeprys, maar hulle mag stel hulle in staat tot angsaanjaende en bloedstollende optredes. God en die Lam heers met 'n ystervuis, verslaan die nasies en laat die bloed in dik strome van $1600 \mathrm{~km}$ lank en so hoog soos perdetooms vloei (9:15; $19: 15 ; 19: 2,21 ; 14: 20)$. Aan die einde van die stryd gooi hulle die bose magte in 'n poel van vuur en swael waar hulle vir ewig, dag en nag, gepynig word (20:10). Die skrywer huiwer selfs nie om die doodmaak van kinders aan goddelike ingryping toe te skryf $(2: 23){ }^{26}$ Die aarde is dus 'n woeste, bloedige strydperk waarin die bose met alle moontlike geweld aangepak word. Selfs die goddelike sfeer is egter nie van geweld afgesluit nie. In die hemel is ook die engele in 'n lewensgevaarlike stryd gedompel en intens aan die oorlog voer (12:7).

Ook die geloofsgemeenskap is wel volgelinge van die Lam, maar hulle tree nie juis soos lammers op nie. In een van die veelbesproke voorbeelde word hulle na die uitskakeling van hulle bose opponente in 18:2, 6-8 opgeroep om die vyand dubbeld terug te betaal vir die skade wat hulle aangedoen is. Vele pogings word in navorsing aangewend om te keer dat hierdie vers as wraakgierige afrekening met die opponent verstaan word. Die dubbele vergelding is 'n ekstreme daad, veral as in gedagte gehou word hoeveel erger dit is as die moontlikheid van vergelding wat in die wet toegelaat is. Lex talionis was oorspronklik daarop ingestel dat die straf by 'n oortreding pas, maar in Openbaring 18 pas die vergelding nie. ${ }^{27}$ Selfs gelowiges kan deur God se ystersepter soos kleiplotte stukkend geslaan word as hulle nie waaksaam is nie (2:27). Beale (1999:901), byvoorbeeld, dink dat die opmerking beteken dat Babilon regverdig ooreenkomstig haar dade terugbetaal moet word en dat dit dus nie as ongebreidelde weerwraak verstaan moet word nie. Wat egter met Babilon in Openbaring 18 gebeur, word al vroeër in die boek op 'n ander manier uitgedruk. In die episode wat handel oor die twee getuies in 11:1-14 word hulle 'getuienis' op 'n dubbelsinnige manier uitgebeeld. Hulle moet die nasies treiter en doodmaak. Die taal wat hier gebruik word, is so dubbelsinnig dat dit maklik na enige kant toe verstaan

25.Oecumenius (Oec. 6.13.2) het reeds al oor die benaming dier opgemerk dat dit simbolies daarop wys dat die Antichris wreed, onmenslik en gierig is.

26.Die impak van die beeld blyk uit die subtiele wysiging in die Afrikaanse vertaling van 1983 waar dit met 'volgelinge' vertaal word, asof dit die geestelike ondersteuners van die vrou beteken. Vergelyk dit met Bousset (1906) se meer realistiese uitleg en ook sy opsomming van die aard van die uitspraak: 'Die eignen Kinder des Weibes sind gemeint, das Weib soll an seinene Kindern gestraft warden, "daher die harte Drohung'"' [Die eie kinders van die vrou word bedoel. Die vrou word aan haar eie kinders gestraf, vandaar die kwaai dreigement]. Greijdanus (1925:83) verwerp ook ' $n$ simboliese betekenis en beklemtoon dat dit om die vrou se fisieke kinders gaan: 'In hen word hunne moeder gestraft.' Hy vervolg, byna verskonend, dat dit vir die kinders nie ' $\mathrm{n}$ besondere straf is nie, maar wel vir hulle ma, 'die van alle hare kinderen op zoo ontroerende wijze beroofd zal worden'. Indien daar soos kommentators soms opmerk, 'n verband tussen hierdie episode en die nakomelinge van Agab is, is die etiese uitdagings van die gedeelte wat sulke wrede nakome straf aan die Menseseun toeskryf met materiaal wat histories swaar met geweld
belas is sovel ernstiger.

27.Kensky (2010:247) bespreek voorbeelde van pogings om die ekstreme aard van die uitspraak te verminder en redeneer dat die straf van Babilon God se oordeel die uitspraak te verminder en redeneer dat die straf van Babilon God se oordeel
wil regverdig. Die probleem is egter nie die oordeel nie, maar die ekstreme, wrede aard daarvan wat God nie beter as die gewelddadige vyande laat lyk nie. 
kan word en ook die grens tussen gewelddadigheid en geweldloosheid vloeiend maak. Aan die een kant is hulle getuienis oënskynlik simbolies, want hulle spreek die nasies aan met 'vuur uit hulle monde' (11:5). Aan die ander kant neig hulle optrede na letterlike geweld wanneer die vernietigende gevolge sigbaar word as hulle getuienis verwerp sou word: 'Só moet elkeen doodgemaak word wat hulle kwaad sal wil aandoen.' Die daaropvolgende vers 6 bevraagteken verder die suggestie dat dit gaan om die vyand se 'geestelike dood' (Beale 1999:581). In die vers tref die getuies die aarde met allerhande plae so dikwels as hulle dit nodig vind. Die ego van die Egiptiese plae beteken nie noodwendig dat hierdie taal simbolies is nie. Die gevolge van Moses se getuienis het immers ook die letterlike dood van die vyand ingesluit. ${ }^{28}$ Juis omdat die taal in die gedeelte oor die getuies so gewelddadig is, kon navorsers soos Satake (1966) redeneer dat hulle taak is om straf uit te deel eerder as om te getuig. Die interpretasie toon dat die dubbelsinnigheid van die uitbeelding gapings in die teks verteenwoordig wat dit vatbaar maak vir 'n gewelddadige siening.

Dit is egter nie net die gewelddadige taal nie, maar ook die ideologiese subteks wat 'n vraagteken agter Openbaring se nie-gewelddadigheid plaas. Op 'n dieper vlak word die teks met 'n agonisme deurdring: dit onthul 'n magstryd tussen partye wat by die boek betrokke is. Die magstryd is byvoorbeeld duidelik in die episode wat handel oor die twee getuies. Hulle optrede toon onmiskenbaar hulle bonatuurlike 'mag' (11:6) wat hulle van God die 'Almagtige' (1:8) en van Jesus ontvang (1:6). Hulle mag is daarom onaanvegbaar en sterker as alle ander bose en gewelddadige magte (kyk bv. 5:12; 4:11; 7:12; 9:3, 19, 11:6; 19:1). Dit lyk dus na 'n positiewe, goddelike mag, wat, soos Farmer (1997:115-116) dink, dring, oorreed en verhoudinge soek.

Hierdie oënskynlike positiewe beskrywing van die goddelike mag is egter inderwaarheid 'n goddelike hegemonie met ' $n$ dwangmatige karakter, soos Farmer (1997:156) ook uitwys. Ook ten opsigte van God se mag herken die navorsing dus 'n spanning tussen gewelddadigheid en geweldloosheid. ${ }^{29} \mathrm{God}$ is in sommige uitsprake in die boek die almagtige Skepper en Regter wat die verloop van die geskiedenis onstuitbaar stuur en wat die uiteindelike vernietiging van die wêreld voorsien. Terselfdertyd word die mag op hulle wat daarvan verskil, afgedwing. Mense wat nie deel is van die skrywer se groep nie en wat nie sy profesie onderskryf nie, word uitgebeeld as vyande wat uitgesluit moet word en wat uiteindelik deur God se magtige ingryping vernietig sal word. Dit geld selfs van mense uit die skrywer se naaste binnekring: in die sewe briewe aan die gemeentes maak hy spesiale beloftes vir

28. Beasley-Murray (1983:184) laat die moontlikheid oop dat die skrywer van Openbaring waarskynlik die letterlike vervulling van die Messiaanse plae verwag het, maar hou ook rekening met 'n simboliese verstaan daarvan.

29.Elders relativeer Farmer (1997:118) harde taal in Openbaring deur terug te val op die simboliek van die boek wat ' $n$ openheid skep vir ' $n$ verbeeldingryke herinterpretasie. Die dwangmatigheid van die magstaal wys op die skrywer se oortuiging dat God se oorwinning oor die kwaad onstuitbaar is. Terselfdertyd dui die sagter, geweldlose taal van Openbaring daarop dat die oorwinning deur verlossende liefde sal plaasvind. Sy siening is 'n dapper poging om die probleem te verlossende liefde sal plaasvind. Sy siening is 'n dapper
hanteer, maar oorinterpreteer die oorspronklike teks. mense wat deel is van die sy gemeenskap, maar spreek hy 'n oordeel uit wanneer hulle aan 'n afwykende leer vashou (2:20-24).

Só 'n goddelike hegemonie met hierdie soort aansprake op en opeising van goddelike gesag kan 'n vernietigende effek hê, soos deur Jurgensmeyer (2003) uitgespel word:

In purely religious battles, waged in divine time and with heaven's rewards, there is no need to compromise one's goals. There is no need, also, to contend with society's laws and limitations when one is obeying a higher authority. In spiritualizing violence, therefore, religion gives the resources of violence a remarkable power. (p. 4)

Openbaring beskryf dus by tye 'n etos op 'n manier en deur 'n agonistiese, gewelddadige taalgebruik wat in konflik staan met sy nie-gewelddadige boodskap. Dit kan nie geïnterpreteer word asof dit maar ' $n$ manier van praat is wat nie 'n wesenlike impak het nie. Dat taal in eie reg gewelddadig kan wees en werk, is nie 'n moderne insig nie en word hier nie onbillik as maatstaf vir die teks gebruik nie. Dit is reeds in die vroegste Christelike tradisies besef, soos blyk uit die uitspraak in die Bergrede dat selfs 'n enkele skelwoord, soos Raka, gewelddadig is (Matt 5:22). Trouens, hierdie Matteaanse insig sou net so kon geld vir die feit dat die skrywer van Openbaring sy teenstander 'Isebel' noem en haar daarmee as een van die berugste karakters in sy godsdienstige tradisie benoem. Deur hierdie benoeming van 'n medegelowige word die persoon verneder, verdag gemaak en uitgesluit. Des te meer omdat naamgewing in bybelse tye identiteit toegeken het. Die benaming is dus ' $n$ voorbeeld van verbale geweld.

Ook kommerwekkend is die onvermydelike invloed van gewelddadige taal op die denke van lesers. Hulle word deur gewelddadige taal ingetrek in 'n ervaringswêreld wat deursuur is met harde en destruktiewe agonisme. Sulke taal, soos moderne sosio-linguistiek uitwys, kan vernietigender wees as fisieke geweld - veral wanneer dit boonop deur godsdiens gelegitimeer en ondersteun word. Taal wat ander demoniseer en wat mense as óf goed óf boos tipeer, plaas mense in ' $n$ bitter, agonistiese sfeer wat opposisie teen mekaar aanvuur en 'n gevaarlike teelaarde vir nog meer geweld skep. Die gevolge van sulke taal kan lesers verlei om te wil deel in die boek se haat teenoor Satan en sy volgelinge (Neufeld 2011:129) en om dan sulke mense wat anders dink en doen, as die vyand te beskou wat verdien om geëlimineer te word. ${ }^{30}$ Sulke taal lei tot uitsluiting en minagting vir 'n gewaande goddelose vyand met wie'n mens nie onderhandel nie. 'n Agonisties ingestelde godsdiens is vernietigend, veral waar dit gedryf word deur 'n fundamentalisme wat eie waarheid vergoddelik ten koste van ander en deur 'n gees van martelaarskap by groepe wat hulleself as slagoffers van verdrukking sien (Huber 2010:55,58). Die resepsiegeskiedenis van Openbaring bewys genoegsaam hoe die boek tot geweld aangestig het. Hieruit blyk die ironie dat dit een ding is om

30.Kyk Kitts en Jerryson (2014:223-233) vir voorbeeld van ekstreme geweldsdade wat deur godsdiens gelegitimeer word. Ook Streett (2012:238 e.v.) bied waardevolle insigte oor die gewelddadige gevolge van geweldstaal. 
geweldloosheid voor te staan, maar iets anders om dit op 'n geweldlose manier aan te bied..$^{31}$

Taal as 'n sosiale konstruk is nie bloot ' $n$ weerspieëling van bepaalde realiteite nie, maar skep en hervestig denke, ervarings en werklikhede. Dit gebeur waar taal mense blootstel aan, deurweek met of afstomp vir geweld, maar ook wanneer taal self op openlike of verborge wyse vorme van geweld herbevestig of bevorder. Taal kan die inherente waarde en menslikheid van ander wesenlik aantas, soos verder ook sal blyk uit die volgende bespreking van Openbaring se gendering. ${ }^{32}$

\section{Gender-geweld}

'n Spesifieke voorbeeld van die gewelddadige impak van taal, kan in die wyse waarop Openbaring oor gender praat gevind word. Dit verdien 'n bespreking op sy eie omdat gendertaal so uitgebreid in die boek gebruik word en só 'n impak op sy boodskap van geweldloosheid het.

\section{Oënskynlik positief}

Op die oog af sou navorsers dikwels uitsprake van Openbaring oor vroue as positief kon aanvaar omdat hulle immers gebruik word om die weerloosheid van die kerk te teken teenoor die geweld wat daarteen aangestig word. Die aksent op weerloosheid deur die gebruik van vrouetaal dien dus om die aaklige gesig van geweld meer intens uit te beeld en te ontmasker. Die kerk is in die aangesig van die kwaadwillige geweld so weerloos soos 'n swanger vrou wat by geboorte deur 'n draak aangeval word (Op 12). By implikasie wys dit ook op God se hoedende mag, want sy word nie deur 'n beskermende Opperwese in die steek gelaat nie. God berei 'n veilige plek in die woestyn waar sy vir 1260 dae veilig is (12:6). Openbaring se skrywer versinnebeeld deur haar, as die swakste onder swakkes, die getroue voorsienigheid van God. Dit lyk ook postief wanneer die Nuwe Jerusalem, die woonplek van God (Op 21) met die beeld van 'n bruid as die ideale beeld vir reinheid weergegee word. Haar reinheid is des te meer opvallend in die lig van die agonistiese versinnebeelding van haar teenstander as die gewelddadige Babilon, die oervyand van Israel wat deur die hoer as oersimbool van onreinheid en promiskuïteit uitgebeeld word. Teenoor die onreinheid en ontrouheid van die opponente, staan die kerk as bruid dus nog sterker as 'n positiewe simbool uit.

Naas hierdie twee beelde is daar die figuur van die 'profetes' Isebel in 2:20. Sy word slegs een keer genoem en dan in

31.Die misbruik van Openbaring om geweld aan te stig, gebeur veral wanneer eksterne faktore geloofsgemeenskappe laat voel hulle word vervolg. Hulle resoneer dan met die hoogs emosionele taal van Openbaring, herinterpreteer die teks as ' $n$ aansporing tot weerstand en word selfs by tye tot geweld gedryf. Beelde uit Openbaring word gebruik om verset te regverdig as 'n heilige oorlog teen ' $n$ eksterne bedreiging van 'n hatige vyand (kyk verder Kippenberg 2011:38 hieroor).

32.Jack (2001:151) verbind hierdie insig met dié van dekonstruksie, naamlik dat taal realiteit skep en dit verstaanbaar maak en nie maar bloot daarna verwys nie. Zizek (2008:1) het, diepsinning, selfs daarop gewys dat geweld nie net werk in taal wat mishandel enenissisteem pekonomiese en politieke sisteme dikwels besonder gew gevolge het. Hierdie artikel wil juis die glad-funksionerende sisteme agte Openbaring se diskoers en die resepsie daarvan van nader bekyk. Dit kan slegs kortliks binne die beperkinge van hierdie artikel gedoen word. vryblywende taal. Selfs oor haar sou 'n mens positiewe argumente kon aanvoer: Sommige lesers wys daarop dat haar karakter impliseer dat vroue belangrike leiersposisies in die vroeë kerk beklee het (Schüssler-Fiorenza 1993:17). Dit word daardeur bevestig dat Johannes skynbaar nie gekant is teen vroue wat profeteer nie, maar teen vroue wat vals profete is en mense tot kettery verlei (2:20).

Sommige lesers mag ook die waarde in die uitbeelding van Babilon as 'n hoer terugvind (Op 17-18). ${ }^{33}$ Die simbool herinner aan die Ou-Testamentiese metafoor vir Israel se ontrouheid aan hulle verbondsverhouding met God deur hulle verval in afgodery. Dat dit 'n saak is wat na aan die skrywer van Openbaring se hart lê, is duidelik deurdat Isebel ook uitdruklik vereenselwig word met afgodery omdat sy mense verlei tot die eet van afgodsoffers (2:20; kyk ook 17:1).

Lesers sou Openbaring se vrouekarakters positief ervaar weens hulle simboliese betekenis om bepaalde geloofservaringe uit te beeld. Die fokus op die betekenis is 'n rede waarom die taal oor vroue self min aandag kry. Die positiewe waardering word egter onder druk geplaas wanneer die wyse waarop die simboliek ter sprake gebring is en die onderliggende diskoers onder loep geneem word - soos nou gedoen moet word.

\section{Gendering $^{34}$ van goed en kwaad}

'n Magdom nuwe interpretasies van Openbaring het begin om die implikasies en gevolge van die uitbeelding van die boodskap in terme van vroue uit te spel. ${ }^{35}$ Hierdie genderstudies het veral onder invloed van feministiese benaderings na vore gekom. ${ }^{36}$ Vir sulke navorsers was die boek se gendering ' $\mathrm{n}$ aanduiding van 'n diskriminerende subteks wat die boek se sterk fokus op geregtigheid ondermyn en selfs verduister het.

Om die kritiek na waarde te skat, moet die begrip gendering kortliks beskryf word. Die term wys op 'n voortgaande proses waarin gepolariseerde, ekstreme voorstellinge van die geslagte oorgeneem, bevestig en gebruik word (Gilgun \& McLeod 1993:170). ${ }^{37}$ Nie alle vorme van gendering is noodwendig negatief, neerhalend of afbrekend nie. Dit gebeur alleen maar waar gendering op 'n dieper vlak die magsposisies van mans en die hegemonie van die patriargie onaangetas laat of ten koste van vroue handhaaf.

33.Kyk Goodfriend (1992) en Budin (2006). Glancy and Moore (2011) se bespreking bied nuttige agtergrond vir die verstaan van die beskrywing in Openbaring 17-18 van Babilon as 'n prostituut. Hulle navorsing is gebaseer op sosiale realia eerder as op die gebruiklike literêre en intertekstuele motiewe. Sulke inligting bring die negatiewe impak van die benoeming sterker na vore.

34. Hier word doelbewus die neologisme gendering ook in Afrikaans gebruik eerder as ander begrippe soos seksualisering (wat' $n$ aspek van gendering is).

35.Vir feministiese interpretasies van Openbaring, kyk Jack (2001:149-162) en die debat in Huber (2010:32-40). Latere interpretasies van Openbaring is meer krities ten opsigte van die uitbeelding van vrouekarakters.

36.Jack (2001:153) dui aan dat Stanton reeds in 1895 Openbaring se taal oor vroue as neerhalend uitgewys het. Hoewel die kritiek dus vroeg uitgespreek is, is dit eers baie onlangs op 'n meer sistematiese manier geanaliseer.

37.Gilgun and Mcleod (1993:173) beklemtoon tereg dat nie alle diskoerse negatief of hegemonies is nie. Sommige kan speels en selfs egalitaries wees. Die aard van so 'n diskoers hang af van die waardes, stories, mites, verwagtinge en reëls wat in die betrokke diskoers funksioneer. 
Gedeeltes van Openbaring kan as 'n voorbeeld van afknouerige en afbrekende gendering beskou word. Dit is ook waar van die uitbeelding van goeie sowel as bose karakters. ${ }^{38}$ Die bruilofsimbole met begrippe soos bruid en vrou van die Lam $(21: 2,9)$ is om verskeie redes opvallend. Die skrywer van Openbaring gebruik nie beskikbare en gebruiklike nie-gender beelde vir die kerk wat elders in die Nuwe Testament voorkom nie (bv. volk van God, liggaam van Christus, heiliges, tempel van God), maar kies eerder vir hierdie gendersimbole. Daarmee deel hy ' $n$ bepaalde opvatting in die sosiale diskoers wat daarop neerkom dat die kerk as bruid ' $n$ vrou is wat haar identiteit ervaar in en verkry deur haar huweliksverhouding met 'n man. Hy onderskryf daarmee dat die vrou se rol dié is van die onderdanige, rein huishoudster en potensiële moeder in 'n patriargale, hierargiese sisteem. ${ }^{39}$ Haar 'reinheid' wat gevind kan word in haar goeie dade (19:8) beklemtoon wel die noodsaaklikheid van die kerk se geestelike getrouheid en etiese lewensstyl, maar die beelde self het die potensiaal om afbrekende genderrolle te bekragtig en te versterk. Só 'n gendering hou moralistiese en gedienstige ideale aan vroue voor: hulle moet in terme van bybelse idees van vroue ordentlik, eerbiedig en onbesproke wees in die vervulling van hulle sosiale rol as hulp vir en voorwerp van manlike begeerte en geselskap (21:2). Die beelde (ook die verhaallyn) teken die bruidegom as die oorheersende figuur wat lei, kontroleer en beheer, terwyl die bruid die passiewe karakter is wie se lot onder beheer van die man is. ${ }^{40}$

Ook die uitbeelding van die bose vroue in Openbaring weerspieël 'n gendering wat vroue uitbuit en afknou. Die profetes in Tiatire (2:20), 'n medegelowige van die skrywer en 'n gemeentelid, word 'Isebel' genoem. Isebel is een van die berugste figure in die geskiedenis van Israel. Om met haar vereenselwig te word, is reeds vernederend. Dat Openbaring se skrywer die punt wil benadruk, blyk uit sy begeleidende beskrywing van die profetes in 2:20-23 in terme van seksuele promiskuiteit met gelaaide woorde soos onsedelikheid, verlei en owerspel. Dit gebeur ook in Openbaring 17-18 waar die stad Babilon in genderterme as 'n prostituut beskryf word. Die boosheid van Rome as die magtige status quo en as politieke hegemonie, word deur die skrywer van

38. Die bose karakters in die boek word meestal as vroue (Isebel en die prostituut of as wilde diere (die draak en twee diere) uitgebeeld - ' $n$ groepering wat veelseggend is. Dit is verder veral opvallend dat godsdienstige aktiviste dikwels hulle opponente as kosmiese vyande uitbeeld, soos wat hier gebeur met die beskrywing van die draak en sy diere wat die wêreld wil onderwerp (kyk hieroor Jurgensmeyer 2003 wat daarop wys dat hierdie benadering dikwels dien as motivering om die opponente te vermoor)

39.Kyk Sebasta (1997:529-541) vir die rol van klere in uitbeelding van vrouens se tradisionele rol in Rome. 'n Vrou se klere is beskou as ' $n$ aanduiding van haa private rol as beskermer van haar liggaam en seksualiteit en toon die verwagtinge van die destydse samelewing van 'n deugsame vrou.

40.Sebasta (1997:538) skryf hieroor: 'Integral to this Augustan program was the restoration and honoring of the traditional role and qualities of the Roman woman and her family and household. Augustan ideology expected a proper Roman wife to prove herself a good custos domi. Devoting the fertility of her body to her husband and her labors to his household, she was to waste neither the 'wealth' of her fertility nor her energies. The ideal matron or materfamilias was expected to find fulfillment in her children, deriving from them, as the roots of matron and materfamilias show honor during her lifetime and praise on her tombstone after her death. Her assiduous devotion to her husband's home was configured as the her death. Her assiduous devotion to her husband's home was configured as the task of weaving, which also served as a metaphor for her preoccupation with the material prosperity of her husband's household. Lastly, her role of custos domi also encompassed the ideal of inviolable matronal chastity. She was to be as fertile as "Tellus, industrious as Lucretia, impregnable as Roma. If, in Augustus "words, the "toga-clad race" were the "masters of the world", their wives, dressed in the stola, were the guardians of Rome itself.'
Openbaring vereenselwig met en uitgedruk in die beeld van 'n veragtelike vroulike figuur met losse sedes wat magsdronk is, wat verleidelik in uitspattige kleredrag geklee is en wat alle nasies met haar onsedelikheid besmet $(17: 4 ; 14: 8 ; 18: 3$, 23; 19:2). Hy beskryf Babilon met dieselfde veragting wat sy tydgenote normaalweg teenoor sulke vroue gehad het. As prostituut is sy, volgens hom, die een wat mans met haar skrikwekkende, dodelike mag verlei om onsedelik te raak: mans is slagoffers, vroue is die berekende, listige verleiers. ${ }^{41}$ Sy span alles in om haar mag oor mans te wys. Sy dra goud, juwele en pêrels $(17: 4 ; 18: 16 ; 21: 11,18,19,21)$ en klere van fyn linne $(18: 16 ; 19: 7)$ om hulle aandag te trek. ${ }^{42}$ So listig is sy dat sy 10 konings tot slagoffers van haar gevaarlike bedoelings kan maak. Haar intensies het boonop met selfverryking te maak. Sy manipuleer hulle seksuele begeertes om rykdom en luukshede te bekom. Hoewel sy luuks leef, gebruik die skrywer taal wat haar as straatvrou en 'n egte slet uitmaak. Hierdie beskrywing wys op iemand in die laagste vlak van die samelewing wat haar liggaam op 'n smerige manier vir seksuele bevrediging aan baie mans verkoop. ${ }^{43}$

Wanneer die skrywer dus oor sy teenstanders skryf, beeld hy hulle minagtend uit as vroue en objektiveer hy - tipies van sy tyd - vroue ook nog in terme van hulle seksualiteit en godsdienstige verval. ${ }^{44}$ Die gendering is dus absoluut, stereotipies en gepolariseerd. Met hierdie objektiverende taal word gender en sosiale verhoudinge van die eerste eeu n.C. gereflekteer en versterk, en daarmee saam, ongelykheid, diskriminasie en mishandeling bevorder (Gilgun \& McLeod 1993:171).

Elders in Openbaring word hierdie gendering indirek bevestig deur 'n omgekeerde simbool wat die skrywer vir gelowiges gebruik. Volgens 14:3-4 sal volgelinge van die Lam die nuwe Jerusalem binnegaan omdat hulle hul nie met vroue 'besoedel' het nie en 'kuis' gebly het. Hier is die simboliek skynbaar positief om te wys dat gemeentelede nie met die bose geheul het nie en nie leuenagtig opgetree het nie (14:5). In die simboliek skuil daar egter' $n$ negatiewe opvatting van vroue en seksualiteit. 'n Vrou maak onrein, en boonop is seksuele verhoudinge nie die mees verheffende vorm van sosiale gedrag nie. Dit is selfs 'n prestasie om jou daarvan te weerhou.

Terwyl die simboliese betekenis van hierdie beelde verheffend kan wees in soverre dit aanspoor tot waaksaamheid en

41. Huber (2006:34) merk op: 'For instance, the bride of the Lamb, a feminine-defined symbol, is read as signifying a positive view of male control over the passive and symbol, is read as signifying
sexually powerless female.'

42.Vir die gendering van geweld, kyk Gilgun and McLeod (1993:167-193).

43.Glancy and Moore (2011) wys uit dat die woord wat vir prostituut gebruik word nie na 'n courtesane uit die hoë stand verwys nie, maar na straatvroue wat hulle seksuele dienste in vuil, lewensgevaarlike omstandighede aan mans verkoop. Hulle argumenteer verder (2011:558-559) dat die tatoeëermerk op die vrou se voorkop (17:5) gelykstaande was aan die merk op slawe en dus haar lae status beklemtoon. Boonop merk dit haar as 'n gebruikersvoorwerp wat soos ' $n$ slaa gestraf en uitgewis kan word. Glancy and Moore (2011) se opvatting is in konflik met die rykdom waarmee die hoer verbind word, maar, soos elders, vloei simbole in die gedeelte in mekaar en bring verskillende kontekste in een gedeelte saam.

44.Oor die algemene neiging om beskrywings van vroue te seksualiseer, skryf Sau (2012:3): 'The sexualisation of words for women is considered especially significant by the many feminists who take sexual objectification to be a crucial element, if not the root, of inequalities between women and men.' 
verset teen die afbrekende gevolge van die kwaad, is daar min verheffends aan die minagtende wyse waarop hierdie boodskap ingeklee word. Taal wat die geweldlose funksie van die kerk benadruk, is op sy eie dus gewelddadig. Die taal vir vroue hoort tuis in 'n konteks van magtige mans wat vroue vanuit die perspektief van hulle eie manlikheid beskou en wat aan hulle rolle toeken wat mans van hulle in die samelewing wil hê. Nie net kan mans vroue objektiveer, beledig en afkraak nie, maar boonop reduseer hulle die beelde in terme van seksuele losbandigheid en verleiding. Agter hierdie diskoers skuil die hegemonie van partriargie wat aan vroue ' $n$ identiteit toeken veral in terme van hulle seksualiteit. Teenstanders word swartgesmeer deur hulle as onsedelike vroue uit te maak.

Johannes neem hierdie taal ongereserveerd en selfs berekend oor. Sy strategie is om doelbewus sy teenstanders by sy lesers verdag te maak deur hulle as prostitute te beskryf die mees veragte karakters in sy samelewing. ${ }^{45}$ Paradoksaal en ironies beveg hy die politieke hegemonie van sy tyd met sy eie minagtende en uitbuitende taal teenoor die mees gemarginaliseerde groepe van die samelewing. Hy gebruik taal wat vertel van wrede geweld wanneer beskryf word hoe die 10 konings die prostituut grusaam doodmaak. Die konings haat haar, trek haar kaal uit, eet haar vleis op en verbrand haar met vuur (17:16; 19:3;46 Eseg 23:25-29) - 'n daad wat sommige interpreteerders laat dink dat dit 'n verkragtingstoneel is (17:16; vgl. Huber 2006:43). Die bose word ook, soos 'n slegte prostituut, vernietig (Gilgun \& McLeod 1993:194, 171; Glancy \& Moore 2011:569). Boonop sien Johannes haar lot as welverdiend en as bewys van die regverdige oordeel van God en teken hy hoe 'n hemelse menigte die geweld bly en jubelend besing (18:21-24).

Openbaring se sensitiewe, diepsinnige diskoers oor regverdigheid, verlossing en oordeel is 'n gepaste en dapper uitdaging van ' $n$ wrede en minagtende sosio-politieke sisteem. Dit roep sy lesers op om sulke demoniese geweld vreesloos uit te daag. Die kerk, die afwagtende bruid, moet hom dapper verset teen die kwaad, die prostituut, in vertroue op God se uitkoms. Die oproep word egter in wrede taal gedoen wat selfs 'n gewelddadige houding teenoor die weerloosste van weerloses in die samelewing uitbeeld en versterk. Dit is gewelddadige taal wat die hoogste minagting vir opponente het en wat, ironies genoeg, juis gewelddadigheid teenoor geweldloses sou kon bevorder by lesers wat nie van beter (wil) weet nie.

\section{Goddelike geweld}

Openbaring weerspieël die absolutekloof tussen diegoddelike en die kwaad: dit vertel van God se intense teenstand teen

45.Kyk Vander Stichele (2000:1-11) oor vroulike taal as'n aanval op Babilon. Sy merk op dat dit nie net die opponente verkleineer nie, maar ook eie meerderwaardigheid uitdruk.

46.Daar is duidelik intertekstuele verbande tussen die ekstreme geweldstaal met Ou-Testamentiese gedeeltes soos Esegiël 16:35-41; 23, Jesaja 23:15-17, 25 , 49:26 en Hosea 2:5. Die Ou-Testamentiese tekste vertoon dieselfde kenmerke van die patriargale siening van vroue en van geweld. Openbaring se oorname van die uitsprake oor vroue is kritiekloos - wat nogal opvallend is in die lig van die die uitsprake oor vroue is kritiekloos
spiritualisering van die oorlogstaal. onreg. God se oordeel oor die kwaad is op die oog af die oorheersende tema in die boek: die dreigende swaard van goddelike vergelding hang swaar oor kwaaddoeners. God sal die kwaaddoeners verantwoordelik hou vir hulle bose dade. Niemand nie, nie eers mense in die binnekring van die geloofsgemeenskap, ontsnap God se veroordelende verwerping van die kwaad en geweld nie. Op 'n hoogs morele manier beklemtoon die boek toerekenbaarheid.

Die oordeel van God word in die boek egter by tye met uiters gewelddadige optredes verbind wat soms aaklige en wrede afmetings aanneem. ${ }^{47}$ Die gedagte dat mense nie reg in eie hand neem nie en dus nie gewelddadig moet wees nie, word begrens en omraam deur 'n groter stuk geweld wat aan God toegeskryf word. As mense nie gewelddadig is nie, is God dit inderdaad wel. God, soos die boek laat blyk, is by tye nie minder gewelddadig as wat die vyande van God is nie. Dit blyk byvoorbeeld uit die uiteindelik lot van die bose triade wat in 'n poel van vuur en swawel gegooi word waar hulle dag en nag gepynig word (19:20; 20:14), uit die wrede lot van die prostituut ('n teken van God se oordeel), uit die doodmaak van kinders en selfs uit die moontlike verkragting (2:23).

Ten spyte van vele moontlike interpretasies en selfs van die vae, veelduidige formuleringe in hierdie voorbeelde, is die vernietigende potensiaal van so 'n beskrywing van die goddelike karakter en die gepaardgaande straf groot. Childs het byvoorbeeld opgemerk dat etiek te doen het met die menslike respons op God se karakter. God se heilige karakter was vir Israel 'n norm, soos blyk uit Levitikus 19:2: 'wees heilig, want ek die Here jou God is heilig' en Matteus 6:48 roep op soortgelyke wyse gelowiges op om so volmaak te wees soos wat hulle hemelse Vader volmaak is. 'n Beskrywing van God wat so wreed straf, wat vyande haat en doodmaak, staan nie net in stryd met die liefdesgebod nie (Matt 5; Luk 10; Rom 13), maar kan aanspoor tot dieselfde wrede gedrag deur mense wat dink hulle dien God deur dubbele vergelding en wat aldus hulle regterlike taak uitoefen soos wat in die boek beloof word (20:4; 3:9; 15:4; 20:4). 'n Mens huiwer ook by die gedagte dat mense behae sal skep in die wrede ondergang van hulle teenstanders op grond van die oordeelsuitsprake in Openbaring. Vir sulke perverse emosies is daar genoeg bewyse uit die geskiedenis, soos ook duidelik blyk uit verwysings hierbo. Dit beteken nie dat die oordeel van God 'n kwessie is nie. Hoe God se oordeel verstaan moet word, is eerder op die spel.

\section{Slot}

Die gewelddadigheid van Openbaring as bybelse teks, ook vervleg met en inherent deel van sy geweldloosheid, skep 'n hermeneutiese dilemma vir moderne interpreteerders. ${ }^{48}$ Sy teologie wat God oënskynlik uitbeeld as 'n woedende

47.Kensky (2010:254) wys op die koue, afskrikwekkende oordeelstoneel in Openbaring 21-22 waarin God as ' $n$ bykans gesiglose, onbeweegbare regter uitgebeeld word wat alleen in 'n harde, kliniese regsproses belangstel.

48.Een voorbeeld van die dilemma kan gevind word in die opmerking van Collins (1983:737): 'Revelation 18 is perhaps the passage that has most deeply offended the moral sensibilities of readers, Christian and non-Christian alike.' 
Kryger wat soek en smag na grusame straf, wat opponente met 'n passie haat en blykbaar aktief daarop uit is om hulle te elimineer, is nie geweldloos nie en is moeilik met nie-gewelddadigheid te rym. Ook onversoenbaar met die geweldlose boodskap is die gendering wat vroue verkleineer en in hulle menslikheid aantas asook die taal wat groepe se psige deurtrek met en aftrek in 'n donker en ekstreme atmosfeer van geweld.

Die dilemma kan op verskeie maniere hanteer word. ${ }^{49}$ 'n Fundamentele eerste stap is om vanuit die NuweTestamentiese wetenskap as teks te ondersoek en die teks van Openbaring as vertrekpunt te eerbiedig wanneer oor hierdie probleem nagedink word. Dit is sekerlik algemene oortuiging dat verkleinerende simbole, destruktiewe kommunikasie en vernietigende agonisme in godsdienstige konteks onaanvaarbaar is. Die vraag is in watter mate hierdie sake met goeie reg in Openbaring as teks teruggevind word en hoe oortuigend die argumente daaroor reg aan die teks self laat geskied. Die etos van die Nuwe-Testamentiese wetenskap vra dat die teks ontleed word sonder om die teksgegewens te manipuleer, te probeer rasionaliseer of om na verleentheidshipoteses te gryp om die potensiële impak daarvan te verminder. Dit vra ook 'n bewussyn van die ondersoeker se rol in hierdie dilemma. Net soos die teks gemanipuleer kan word deur moderne lesers wat die teks se gesag wil beskerm, kan die teks ook die slagoffer word van lesers wat gewaande uitwasse daarin wil uitwys wat meer in hulle eie tyd voorkom as in die teks self. Sonder legitieme, deeglike argumente oor die teks en teksresepsie kan lesers van die boek verlei word om gewelddadige taal, inhoude en optredes oor te neem en na te boots of om die bevrydende momente in die teks mis te kyk.

Tweedens word die dilemma dus nie opgelos deur op sy geweldloosheid te fokus en die gewelddadigheid te onderspeel nie. Geweld is endemies aan die boek se geweldloosheid en wesenlik daarmee vervleg. Daar is nie 'n geweldlose 'kern' wat uit die boek soos 'n stuk kwaadaardige groeisel netjies uitgesny kan word en dus as 'n flater afgemaak kan word nie. Hierdie dilemma raak veral die aard van die Bybel as gesaghebbende godsdienstige grondteks. Dit is heel versoberend om deur die dilemma te besef hoeveel kwaad daar ook in en te midde van die lig kan skuil, of, anders gestel, op watter menslike wyse die boodskap van die Bybel uitgebeeld is. Openbaring self dui aan dat die bose nie net in die eksterne magte in Babilon beliggaam is nie, maar soms ook in die gesaghebbende profetiese figuur van Isebel uit die binnekring. Geëkstrapoleer op Openbaring self, beteken dit dat daar in Johannes se skrywe self donker, destruktiewe kolle skuil - net soos bybelse uitsprake oor slawerny wat deur niemand meer as normatief aanvaar word nie. Hierdie insig wys op die dinamiese aard van Bybelinterpretasie: juis vanweë sy beperktheid is die hermeneutiek van terughoudendheid en suspisie by ons om te bly. Trouens die

49.In hierdie slotafdeling word enkele opmerkings gemaak hoe om die dilemma aan te spreek. 'n Deeglike bespreking van oplossings om die probleem te hanteer, vereis ' $n$ afsonderlike analise. Dit is nodig om die probleem te identifiseer as ' $n$ eerste stap tot ' $n$ geloofwaardige oplossing. dilemma van Openbaring se gewelddadigheid wat veral in onlangse tye na vore kom, wys hoe noodsaaklik voortgaande kritiese ondersoek is.

Derdens los argumente wat die geweld van Openbaring as tydgebonde beskou ook nie die hermeneutiese dilemma op nie. Dit is patroniserend om die antieke summier as gewelddadig af te maak en om kontemporêre godsdienstige bewegings te romantiseer asof dit nie donker kante het nie. Moderne godsdienstige diskoers is dikwels deurtrek met gewelddadige vilifikasie en demonisering van teenstanders as die Antichris, 'n Isebel of as magte van die Bose. Juis daarom is die ondersoek van geweld en die onderliggende agonisme in Openbaring so belangrik. Dit probeer verstaan hoekom geweld so 'n houvas het dat die Christelike tradisie selfs in sy mees sentrale boodskap van geweldloosheid so gewelddadig was en steeds is.

Terwyl die vorige punte meer metodologies van aard is, is dit nodig om ook op inhoudelike kwessies te wys wat die dilemma kan help oplos. Die dilemma sal, vierdens, sinvol bekyk kan word deur Openbaring as deel van die Bybel as formerende tekste van die Christendom te lees. Sy harde geweldsuitsprake sowel as sy sagte kant moet met ander bybelse tekste (soos bv. Jesus se vredesuitsprake) vergelyk word. 'n Vergelyking sal wys dat vroeë Christene nie konsekwent net ekstreme taal gebruik het, 'n vergeldende Godsbeeld gehad het en vroue verkleineer het nie. Nog baie werk moet in hierdie verband gedoen word, veral deur individuele bybeltekste te ondersoek.

In die vyfde plek word die dilemma ook aangepak deur te vra na die transformatiewe werking van die boek se inhoud en dus na die bevrydende moment daarin. Die Bybel is, soos hierbo opgemerk, na eie getuienis ingestel op die omvorming van mense en groepe. Die verhaallyn van die Bybel begin, sentreer en eindig immers in die paradys, die tuin en met die vrederyk. Bybelgedeeltes het nie transformatiewe krag nie en boet in aan geldigheid wanneer dit persone se menslikheid geweld aandoen. Soos hierbo uitgewys is, is daar uitnemendheid in Openbaring se afwysing van fisieke geweld, in sy aandrang op brute eerlikheid en gesprek en in sy najaag van geregtigheid. Daar is verskeie dimensies van Openbaring se boodskap wat tans steeds transformatiewe krag het. Nog steeds en selfs meer as ooit tevore, is Openbaring se kritiek teen 'n politieke hegemonie wat totaal boos word wanneer dit geregtigheid ondermyn en ondergrawe, die menslikheid van ander aantas, woorde met swaarde vervang, en die leuen vergoeilik, belangrik in 'n moderne konteks. In hierdie opsigte is die boek tekenend van 'n revolusionêre houding en leefstyl wat van die vernietigende standaarde en praktyke van sy sosiale konteks afwyk. ${ }^{50}$ Dit is hierdie

50.0 penbaring se swaar oordeel oor absolute, goddelose state was' $n$ belangrike teks vir Bonhoeffer tydens sy aanhouding in die tronk, terwyl Boesak (1987) se invloedryke kommentaar wys hoe Openbaring met sy felle oordeel oor korrupte magshebbers hoop en moed aan hulle slagoffers gegee het. Hy (Boesak 1987:133) skryf byvoorbeeld oor die harde straf van die sondaars wat in Openbaring 21:8 beskryf word: 'People who have never been persecuted for their faith or vilified, smeared, and imprisoned because of their testimony for Jesus Christ, will have great difficulty understanding these words of John' (kyk ook verder De Villiers 2013 vir' $n$ vollediger bespreking). 
diepsinnige instelling wat die boek deel laat word het van die Christelike tradisie se rigtinggewende tekste.

Uiteindelik is dit deurslaggewend om die geestelike karakter van Openbaring te beklemtoon. Daar is in die boek se Godsbegrip en in sy konsekwente oproep tot 'n intieme verhouding met God duidelik ook uitnemende momente. God staan, metafories gesproke, by die deur en nooi die gemeenskap uit tot feesviering (3:20). Die boek vertel dus van goddelike afwagting, verlange en geduld. Dit loop uit op 'n idilliese beskrywing van gemeenskaplikheid, versorging en geborgenheid in die paradys as plek van God se teenwoordigheid (21:4). Selfs die verhaallyn van die boek wat andersins donker en dreigend is, vertoon ook sy sagte ligkante meermale en patroonmatig, veral in die interkalasies (tussen die septette) waarin God se beskermende hand oor die geloofsgemeenskap beskryf word (Op 7; 11; 14). Hierdie transformatiewe materiaal maak dit nog meer ironies dat die skrywer sy boodskap so uitvoerig met gewelddadigheid en gewelddadige taal vervleg het.

\section{Erkenning \\ Mededingende belange}

Die outeur verklaar dat hy geen finansiële of persoonlike verbintenis het met enige party wat hom nadelig of voordelig kon beïnvloed het in die skryf van hierdie artikel nie.

\section{Literatuurverwysings}

Aune, D., 1998, Revelation, Thomas Nelson, Nashville. (WBC, 52b).

Bauckham, R., 1993, The theology of the book of Revelation, Cambridge University Press, Cambridge.

Beale, G.K., 1999, The book of Revelation, New International Greek Testament commentary, Eerdmans, Grand Rapids, MI and Cambridge.

Beasley-Murray, G.R., 1983, The book of Revelation, Eerdmans, Grand Rapids.

Boesak, A.A., 1987, Comfort and protest. The Apocalypse from a South African perspective, Westminster, Philadelphia.

Bousset, W., 1906, Die Offenbarung Johannis, Vandenhoeck \& Ruprecht, Göttingen. (KEK, 16).

Bredin, M., 2012, Jesus. Revolutionary of peace: A nonviolent Christology in the book of Revelation, Paternoster, Waynesboro.

Brighton, M.A., 2009, The Sicarii in Josephus's Judean War: Rhetorical analysis and historical observations, Society of Biblical Literature, Atlanta.

Budin, S.L., 2006, 'Prostitute', in M.H. Ditmore (ed.), Encyclopedia of prostitution and sex workers, vol. 1, pp. 33-39, Greenwoord, Westport, CT.

Collins, A.Y., 1983, 'Persecution and vengeance in the book of Revelation', in D. Hellholm (ed.), Apocalypticism in the Mediterranean World and the Near East, pp. 729-748, Mohr Siebeck, Tübingen.

Crossan, J.D., 2007, God and empire: Jesus against Rome. Then and now, HarperCollins, New York.

Crossan, J.D., 2015, How to read the Bible and still be a Christian. Struggling with divine violence from Genesis to Revelation, HarperOne, New York.

De Villiers, P.G.R., 2013 'Hermeneutical reflections on violence in the New Testament', in P.G.R. de Villiers \& Jan-Willem van Henten (eds.), Coping with violence in the New Testament, pp. 245-273, Brill, Leiden.

Farmer, R.L., 1997, Beyond the impasse. The promise of a process hermeneutic Studies in American Biblical Hermeneutics, Mercer, Macon.
Finamore, S.A., 2001, 'Kinder, gentler Apocalypse? René Girard, the book of Revelation, and the bottomless abyss of the unforgettable victim', in T. Grimsrund \& M. Hardin (eds.), Compassionate eschatology: The future as friend, pp. 196-217, Cascade Books, Eugene, OR.

Gilgun, J.F. \& McLeod, L., 1993, 'Gendering violence', Studies in symbolic interactionism 22, 167-193.

Glancy, J.A. \& Moore, S.D., 2011, 'How typical a Roman prostitute is Revelation's "Great Whore"?", JBL 130(3), 551-569.

Goodfriend, E.A., 1992, 'Prostitution', in D.N. Freeman (ed.), The Anchor Bible Dictionary, vol. 5, pp. 421-426, Doubleday, New York, NY.

Greijdanus, S., 1925, De Openbaring des Johannes, H.A. van Bottenburg, Amsterdam. (KNT).

Hays, R., 1997, The moral vision of the New Testament: Community, cross, new creation. A contemporary introduction to New Testament ethics, T\&T Clark, Edinburgh.

Hernandez, J., 2006, Scribal habits and theological influences in the Apocalypse, Mohr Siebeck, Tübingen. (WUNT, 2.218).

Huber, L.R., 2006, Like a bride adorned: Reading metaphor in John's Apocalypse, Emory studies in early Christianity, T\&T Clark, New York, NY and London.

Huber, W., 2010, 'Religion and violence in a globalized world', paper presented at the 11 th Gerd Bucerius Lecture, Washington on 24th June, viewed 20 April 2015, from http://www.ghi-dc.org/files/publications/bulletin/bu047/bu47_051.pdf

Jack, A., 2001, 'Out of wilderness: Feminist perspectives on the book of Revelation', in S. Moyise (ed.), Studies in the book of Revelation, pp. 149-162, T\&T Clark, Edinburgh and New York, NY.

Johns, L., 2003, The Lamb Christology of the Apocalypse of John, Mohr Siebeck, Tübingen.

Jurgensmeyer, M., 2003, Terror in the mind of God: The global rise of religious violence, University of California Press, Berkeley, CA.

Kaminsky, H., 2004, A history of the Hussite Revolution, Wipf \& Stock, Eugene, OR.

Kensky, M.Z., 2010, Trying man, trying God: The divine courtroom in early Jewish and Christian literature, Mohr Siebeck, Tübingen. (WUNT, 2.289).

Kippenberg, H., 2011, Violence as worship. Religious wars in the age of globalisation, Stanford University Press, Stanford.

Kitts, M. \& Jerryson, M., 2014, 'Introduction', Journal of Religion and Violence 2(2), 223-233.

Klassen, W., 1966, 'Vengeance in the Apocalypse of John', CBQ 28, 300-311.

Lawrence, D.H., [1931] 1960, Apocalypse, Heinemann, London.

Longman, T., 1982, 'The divine warrior: the New Testament use of an Old Testament motif', Westminster Theological Journal 44, 290-307.

Martin, D., 2011, The future of Christianity: Reflections on violence and democracy, religion and secularization, Ashgate, Surrey and Burlington.

Mounce, R.H., 1988, The book of Revelation, Eerdmans, Grand Rapids, MI.

Mueller, E., 2011, 'Christological concepts in the book of Revelation-Part 3: The Lamb Christology', Journal of the Adventist Theological Society 22(2), 42-66.

Müller, U.B., 1995, Die Offenbarung des Johannes, Gütersloher Verlagshaus Gerd Mohn, Gütersloh.

Neufeld, T.R., 2011, Killing enmity, violence and the New Testament, Baker Books, Grand Rapids, MI.

Roloff, J., 1984, Die Offenbarung des Johannes, Theologischer Verlag, Zürich.

Rossing, B.R., 2005, 'Apocalyptic violence and politics: End-times fiction for Jews and Christians', Yale University Reflections, viewed 21 April 2015, from http:// reflections.yale.edu/article/end-times-and-end-gamesis-scripture-being-leftbehind/apocalyptic-violence-and-politics-end

Satake, A., 1966, Die Gemeindeordnung in der Johannesapokalypse, Neukirchener, Neukirchner Vluyn.

Saul, J., 2012, 'Feminist philosophy of language', in E.N. Zalta (ed.), The Stanford Encyclopedia of philosophy, viewed 02 May 2015, from http://plato.stanford.edu/ archives/win2012/entries/feminism-language

Schüssler-Fiorenza, E., 1993, Revelation. Vision of a just world, T\&T Clark, Edinburgh.

Sebasta, J.L., 1997, 'Women's costume and feminine civic morality in Augustan Rome', Gender \& History 9(3), 529-541. http://dx.doi.org/10.1111/1468-0424.00074

Streett, M.J., 2012, Here comes the Judge: Violent pacifism in the book of Revelation, Black, London.

Vander Stichele, C., 2000, 'Just a whore. The annihilation of Babylon according to Revelation 17:16', Lectio difficilior. European Electronic Journal for Feminist Exegesis 1, 1-11.

Zizek, S., 2008, Violence, Picador, London. 